\title{
STUDY ON SOME GROUPS OF MICROORGANISM DURING THE FOREST REHABILITATION PROCESS IN SONG MA DISTRICT, SON LA PROVINCE
}

\author{
Nguyen Thi Quyen ${ }^{1}$, Nguyen Van $\operatorname{Sinh}^{2 *}$ \\ ${ }^{1}$ Committee of the Fatherland Front of Song Ma district \\ ${ }^{2}$ Institute of Ecology and Biological Resources, VAST, *nvsinh@gmail.com
}

\begin{abstract}
The paper has made assessement on changes of some soil microorganism groups during the process of forest rehabilitation after shifting cultivation and after clear cutting in Song Ma district, Son La province. Sampling has been made in forest areas naturally regenerated for 4-6; 9-11; $14-16$ and above 20 years after shifting cultivation and after clear cutting. The results have shown that the total aerobic bacteria, the total actinomycetes and the total microfungi have increased from the rehabilitation stage of $4-6$ years $\left(3.12 \times 10^{2} ; 1.23 \times 10^{3}\right.$ and $8.05 \times 10^{2} \mathrm{CFU} / \mathrm{g}$ respectively in forest areas after shifting cultivation and $4.25 \times 10^{4} ; 2.32 \times 10^{3}$ and $7.32 \times 10^{3} \mathrm{CFU} / \mathrm{g}$ respectively in forest areas after clear cutting) to the rehabilitation stage of $\geq 20$ years $\left(3.54 \times 10^{5}\right.$; $2.23 \times 10^{4}$ and $2.51 \times 10^{4} \mathrm{CFU} / \mathrm{g}$ respectively in forest areas after shifting cultivation and $4.35 \times 10^{6}$; $2.72 \times 10^{5}$ and $5.46 \times 10^{5} \mathrm{CFU} / \mathrm{g}$ respectively in forest areas after clear cutting). The capacity in free nitrogen fixation, in cellulose decomposition, in phosphates decomposition, and in polysaccharide production of the aerobic bacteria, of actinomycetes, and of microfungi is lowest during the first forest rehabilitation stage (4-6 years), then it grows and reaches the highest value during the stage of $\geq 20$ years $\left(5.60 \times 10^{3} ; 2.75 \times 10^{4} ; 2.10 \times 10^{3} ; 1.36 \times 10^{4} \mathrm{CFU} / \mathrm{g}\right.$ respectively in forest areas after shifting cultivation and $5.24 \times 10^{3} ; 3.14 \times 10^{5} ; 4.27 \times 10^{4} ; 5.39 \times 10^{4} \mathrm{CFU} / \mathrm{g}$ respectively in forest areas after clear cutting).
\end{abstract}

Keywords: Forest rehabilitation, soil microorganism, Son La, Vietnam.

\section{INTRODUCTION}

Microorganisms play an important role in the decomposition of organic compounds, to ensure the circulation of mineral nutrients in the soil. Conversely, the appropriate biotic and abiotic factors, such as soil, temperature, humidity, soil $\mathrm{pH}$, degree of forest cover ... also support the development of microorganisms both in amount and composition. The practice of shifting cultivation and clear cutting in general and in Song $\mathrm{Ma}$ district of Son $\mathrm{La}$ province in particular, has caused erosion and surface runoff with significant impact on the soil environment and activity of soil microorganisms. The researchers that study the soil quality and the impact of forest on the soil environment must consider the soil microorganism [3]. The study of the distribution and dynamics of the main groups of soil microorganism under forest being in different rehabilitation stages after clear cutting and shifting cultivation will provide scientific data for the planning of protection and sustainable development of forest in Song Ma district, Son La province.

\section{MATERIALS AND METHODS}

\section{Sampling procedure}

Sampling was conducted in September 2014. Samples have been taken from the surface soil layer at the depth of $10 \mathrm{~cm}$, packed in coded nylon bag and kept in temperature $4^{\circ} \mathrm{C}$ untill being analysed. Sampling locations in forest areas naturally regenerated for 4-6; 9-11; 14-16 and above 20 years after shifting cultivation and clear cutting in Song $\mathrm{Ma}$ district, Son $\mathrm{La}$ province are shown in the figure 1.

\section{Isolation environment}

The MPA environment (for defining total aerobic bacteria) (g/l): meat glue 3 ; pepton 5 ; $\mathrm{NaCl} 5$; jelly 20; $\mathrm{H}_{2} \mathrm{O} 1,000 \mathrm{ml}$.

The Czapek environment (for defining total microfungi) (g/l): $\mathrm{NaNO}_{3}$ 3.5; $\mathrm{K}_{2} \mathrm{HPO}_{4}$ 1.5; $\mathrm{MgSO}_{4} 0.5 ; \mathrm{KCl} 0.5 ; \mathrm{FeSO}_{4} 0.1$; glucoza $80 \mathrm{~g}$; jelly $20 ; \mathrm{H}_{2} \mathrm{O} 1,000 \mathrm{ml}$.

The Gauze 1 environment (for defining total actinomycetes) (g/l): soluble starch 10; $\mathrm{K}_{2} \mathrm{HPO}_{4}$ $0.5 ; \mathrm{MgSO}_{4} 0.5 ; \mathrm{KNO}_{3} 1 ; \mathrm{NaCl} 0.5 ; \mathrm{FeSO}_{4} 0.01$; jelly $20 ; \mathrm{H}_{2} \mathrm{O} 1,000 \mathrm{ml}$. 


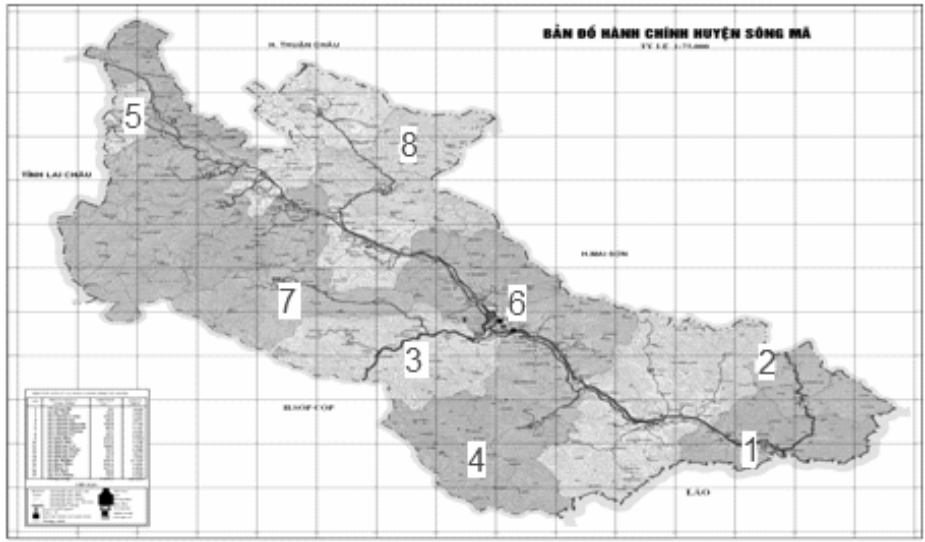

Figure 1. Sampling locations in naturally regenerated secondary forest areas of Song Ma district, Son La province

map source: Department of Resources and Environment, Song Ma district.
Define total aerobic bacteria, actinomycetes and microfungi accoding to Nguyen Lan Dung et al. (1978) [1]; define cellulose decomposing microorganism according to TCVN 6168:2002; define phosphates decomposing microorganism according to TCVN 6167:1996; define free nitrogen fixing microorganism according to TCVN 6166:2002 and define polysaccharide producing microorganism according to Sunil et al. (2013) [3].

\section{RESULTS AND DISCUSSION}

Results of soil sampling on 8 sites of naturally regenerated secondary forest in Song Ma district, Son La province

The soil sampling for analysis of microorganism has been conducted in the areas of secondary forest naturally regenerated after shifting cultivation and clear cutting. The results of soil sampling are shown in table 1 .

Table 1. The results of soil sampling on 8 sites of naturally regenerated secondary forest in Song Ma district, Son La province

\begin{tabular}{|c|c|c|c|c|}
\hline $\begin{array}{l}\text { Sampling } \\
\text { location (on } \\
\text { the map) }\end{array}$ & $\begin{array}{l}\text { The stage } \\
\text { of secondary } \\
\text { forest }\end{array}$ & Sampling site & Soil characteristic & $\begin{array}{l}\text { Forest } \\
\text { group }\end{array}$ \\
\hline 1 & $4-6$ & $\begin{array}{l}\text { Quyet Thang village, } \\
\text { Chieng Khuong commune }\end{array}$ & $\begin{array}{l}\text { Yellow, porous, mixed with } \\
\text { gravel, not much roots and litter }\end{array}$ & \multirow{4}{*}{$\begin{array}{c}\text { After } \\
\text { shifting } \\
\text { cultivation }\end{array}$} \\
\hline 2 & $9-11$ & $\begin{array}{l}\text { Co Dua village, Muong } \\
\text { Sai commune }\end{array}$ & $\begin{array}{l}\text { Golden brown, porous, mixed } \\
\text { with gravel and roots, relative } \\
\text { thick litter }\end{array}$ & \\
\hline 3 & $14-16$ & $\begin{array}{l}\text { Huoi Vang village, Huoi } \\
\text { Mot commune }\end{array}$ & $\begin{array}{l}\text { Brown greyish, porous, not } \\
\text { much small gravel, much } \\
\text { roots and litter }\end{array}$ & \\
\hline 4 & $\geq 20$ & $\begin{array}{l}\text { Huoi Khe village, } \\
\text { Muong Cai commune }\end{array}$ & $\begin{array}{l}\text { Brown greyish, porous, much } \\
\text { roots and litter }\end{array}$ & \\
\hline 5 & $4-6$ & $\begin{array}{l}\text { Pa Lau village, } \mathrm{Pu} \text { Bau } \\
\text { commune }\end{array}$ & $\begin{array}{l}\text { Brown reddish, not much } \\
\text { small gravel, porous, mixed } \\
\text { with roots and litter }\end{array}$ & \multirow{4}{*}{$\begin{array}{l}\text { After clear } \\
\text { cutting }\end{array}$} \\
\hline 6 & $9-11$ & Song Ma town & $\begin{array}{l}\text { Brown greyish, not much } \\
\text { small gravel, porous, mixed } \\
\text { with roots and thick litter }\end{array}$ & \\
\hline 7 & $14-16$ & $\begin{array}{l}\text { Pa Man village, Nam } \\
\text { Man commune }\end{array}$ & $\begin{array}{l}\text { Brown greyish, porous, much } \\
\text { roots and litter }\end{array}$ & \\
\hline 8 & $\geq 20$ & $\begin{array}{l}\text { Na San village, Chieng } \\
\text { Phung commune }\end{array}$ & $\begin{array}{l}\text { Brown greyish, porous, much } \\
\text { roots and litter }\end{array}$ & \\
\hline
\end{tabular}


The data in table 1 shows the influence of the forest rehabilitation stages on the morphological characteristics of the soil. With the time, the litter became thicker, the surface soil layer changed the color from yellow to golden brown and brown greyish (in the forest areas developed after shifting cultivation) and from brown reddish to brown greyish (in the forest areas developed after clear cutting). The differences depend mainly on the site characteristics and plant components at the rehabilitation stages. The soil under the forest areas at the first rehabilitation stages after clear cutting still has the characteristics of the forest soil, the surface soil layer and the litter are still relative thick what create favourite conditions for the forest rehabilitation. The soil under the forest areas at the first rehabilitation stages after shifting cultivation has been eroded, therefore the process of forming surface layer and litter and of restoring the tree species composition here is slower than in the areas after clear cutting.

Some microorganism groups in the soil of forest areas developed after clear cutting and shifting cultivation in Song Ma district

The 8 collected soil samples have been analysed to define the morphological characteristics and number of aerobic bacteria, actinomycetes and microfungi. The figure 2 and table 2 show the results of isolation and analysis of these microorganism groups.
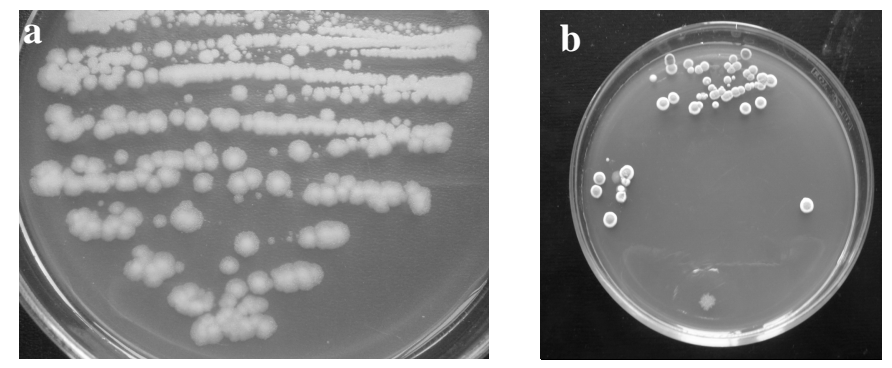

Figure 2. The pictures of the aerobic bacteria (a) and actinomycetes (b) isolated from samples collected in Song $\mathrm{Ma}$ district

Table 2. Number of microorganism (CFU/g) in different forest rehabilitation stages in Song Ma district, Son La province

\begin{tabular}{clllll}
\hline \multirow{2}{*}{$\begin{array}{c}\text { Sampling } \\
\text { location } \\
\text { (on the map) }\end{array}$} & \multicolumn{1}{c}{ Microorganism group } & \multicolumn{4}{c}{$\begin{array}{c}\text { Number of microorganism (CFU/g) different } \\
\text { forest rehabilitation stages (years) }\end{array}$} \\
\cline { 3 - 6 } & & $4-6$ & $9-11$ & $14-16$ & $\geq 20$ \\
\hline & Forest group: after shifting cultivation & & & \\
2 & Free nitrogen fixing & $2.40 \times 10^{1}$ & $28.0 \times 10^{2}$ & $3.40 \times 10^{3}$ & $5.60 \times 10^{3}$ \\
3 & Cellulose decomposing & $4.51 \times 10^{2}$ & $12.5 \times 10^{2}$ & $2.45 \times 10^{4}$ & $2.75 \times 10^{4}$ \\
4 & Phosphates decomposing & $1.62 \times 10^{1}$ & $15.0 \times 10^{2}$ & $2.05 \times 10^{3}$ & $2.10 \times 10^{3}$ \\
& Polysaccharide producing & $2.67 \times 10^{2}$ & $2.35 \times 10^{2}$ & $4.21 \times 10^{3}$ & $1.36 \times 10^{4}$ \\
\hline & Forest group: after clear cutting & & & & \\
6 & Free nitrogen fixing & $3.56 \times 10^{2}$ & $3.66 \times 10^{3}$ & $2.15 \times 10^{3}$ & $5.24 \times 10^{3}$ \\
7 & Cellulose decomposing & $6.43 \times 10^{3}$ & $4.21 \times 10^{4}$ & $3.41 \times 10^{4}$ & $3.14 \times 10^{5}$ \\
8 & Phosphates decomposing & $5.72 \times 10^{2}$ & $6.34 \times 10^{2}$ & $2.73 \times 10^{3}$ & $4.27 \times 10^{4}$ \\
& Polysaccharide producing & $4.98 \times 10^{3}$ & $4.32 \times 10^{3}$ & $4.22 \times 10^{4}$ & $5.39 \times 10^{4}$ \\
\hline
\end{tabular}

The results in table 2 has shown that total aerobic bacteria, actinomycetes and microfungi in two forest groups (after shifting cultivation and after clear cutting) has been increased with forest rehabilitation stages. At the rehabilitation stage of 4-6 years, the number of aerobic bacteria is $3.12 \times 10^{2}$, of actinomycetes is
$1.23 \times 10^{3}$, and of microfungi is $8.05 \times 10^{2} \mathrm{CFU} / \mathrm{g}$. These numbers have been increased through the rehabilitation stages of 9-11 and of 14-16 years and reached highest values at the rehabilitation stage of $\geq 20$ years with the values of $3.54 \times 10^{5}$; $2.23 \times 10^{4}$ and $2.51 \times 10^{4} \mathrm{CFU} / \mathrm{g}$ respectively. The comparision of the data presented in table 2 has 
shown that the number of aerobic bacteria, actinomycetes and total micro-fungi of the soil under forest group developed after clear cutting always (in all 4 forest rehabilitation stages) higher than this of the soil under forest group developed after shifting cultivation. The difference in number of aerobic bacteria and total microfungi, especially in the later forest rehabilitation stages, is higher than the difference in number of actinomycetes.

Capacity of the different groups of microorganism in free nitrogen fixation, in cellulose decomposition, in phosphates decomposition, and in polysaccharide production

After isolation of three groups of microorganism (total aerobic bacteria, total actinomycetes, total microfungi), the capacity of microorganism in free nitrogen fixation, in cellulose decomposition, in phosphates decomposition, and in polysaccharide production has been analysed. The results are presented in the figure 3 and table 3 .
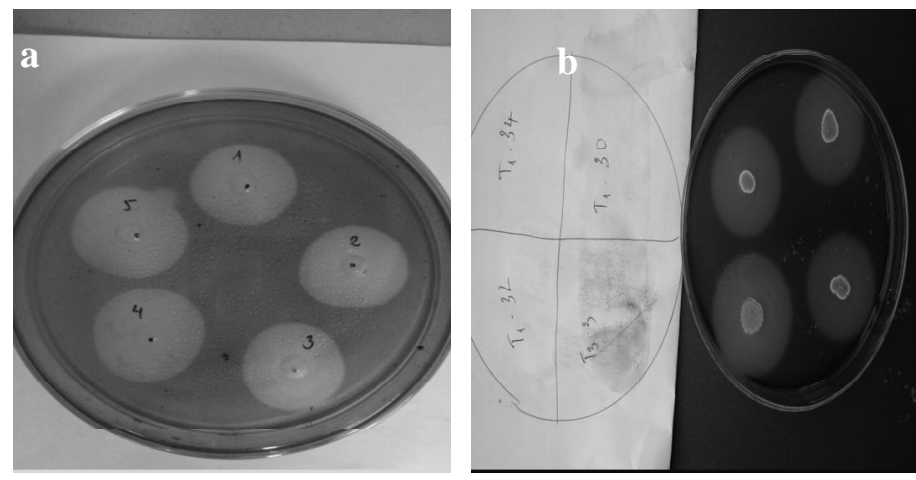

Figure 3. Capacity in cellulose decomposition of bacteria (a) and of actinomycetes (b) isolated from the soil of secondary forest in Song $\mathrm{Ma}$ district

Table 3. The number of free nitrogen fixing, cellulose decomposing, phosphates decomposing and polysaccharide producing microorganism at different forest rehabilitation stages

\begin{tabular}{|c|c|c|c|c|c|}
\hline \multirow{2}{*}{$\begin{array}{c}\text { Sampling } \\
\text { location } \\
\text { (on the map) }\end{array}$} & \multirow[t]{2}{*}{ Microorganism group } & \multicolumn{4}{|c|}{$\begin{array}{c}\text { Number of microorganism (CFU/g) different } \\
\text { forest rehabilitation stages (years) }\end{array}$} \\
\hline & & $4-6$ & $9-11$ & $14-16$ & $\geq 20$ \\
\hline & \multicolumn{5}{|c|}{ Forest group: after shifting cultivation } \\
\hline 1 & Free nitrogen fixing & $2.40 \times 10^{1}$ & $28.0 \times 10^{2}$ & $3.40 \times 10^{3}$ & $5.60 \times 10^{3}$ \\
\hline 2 & Cellulose decomposing & $4.51 \times 10^{2}$ & $12.5 \times 10^{2}$ & $2.45 \times 10^{4}$ & $2.75 \times 10^{4}$ \\
\hline 3 & Phosphates decomposing & $1.62 \times 10^{1}$ & $15.0 \times 10^{2}$ & $2.05 \times 10^{3}$ & $2.10 \times 10^{3}$ \\
\hline 4 & Polysaccharide producing & $2.67 \times 10^{2}$ & $2.35 \times 10^{2}$ & $4.21 \times 10^{3}$ & $1.36 \times 10^{4}$ \\
\hline \multicolumn{6}{|c|}{ Forest group: after clear cutting } \\
\hline 5 & Free nitrogen fixing & $3.56 \times 10^{2}$ & $3.66 \times 10^{3}$ & $2.15 \times 10^{3}$ & $5.24 \times 10^{3}$ \\
\hline 6 & Cellulose decomposing & $6.43 \times 10^{3}$ & $4.21 \times 10^{4}$ & $3.41 \times 10^{4}$ & $3.14 \times 10^{5}$ \\
\hline 7 & Phosphates decomposing & $5.72 \times 10^{2}$ & $6.34 \times 10^{2}$ & $2.73 \times 10^{3}$ & $4.27 \times 10^{4}$ \\
\hline 8 & Polysaccharide producing & $4.98 \times 10^{3}$ & $4.32 \times 10^{3}$ & $4.22 \times 10^{4}$ & $5.39 \times 10^{4}$ \\
\hline
\end{tabular}

The data in the table 3 shows that capacity in free nitrogen fixation, in cellulose decomposition, in phosphates decomposition, and in polysaccharide production of the aerobic bacteria, of actinomycetes, and of microfungi vary much with the time. It is lowest during the first forest rehabilitation stage (4-6 years), then it grows and reaches the highest value during the stage of $\geq 20$ years. In the forest group developed after shifting cultivation, the numbers of free nitrogen fixing and phosphates decomposing microorganism are lowest $\left(2.40 \times 10^{1}, 1.62 \times 10^{1} \mathrm{CFU} / \mathrm{g}\right.$ respectively), the numbers of cellulose decomposing and 
Study on some groups of microorganism during the forest

polysaccharide producing microorganism are higher $\quad\left(4.51 \times 10^{2}, \quad 2.67 \times 10^{2} \quad \mathrm{CFU} / \mathrm{g}\right.$ respectively). The quantity of these microorganism groups has been increased with the duration of forest rehabilitation, so that at the rehabilitation stage of $\geq 20$ years the number of free nitrogen fixing, cellulose decomposing and polysaccharide producing microorganism has been increased 100 -fold $\left(5.60 \times 10^{3}\right.$; $2.75 \times 10^{4}$ and $1.36 \times 10^{4} \mathrm{CFU} / \mathrm{g}$ respectively); whereas the number of phosphates decomposing microorganism has been increased 1000-fold $\left(1.36 \times 10^{4} \quad \mathrm{CFU} / \mathrm{g}\right)$. The quantity of microorganism groups in the forest group developed after clear cutting is 10 -fold higher than in the forest group developed after shifting cultivation. At the rehabilitation stage of 4-6 years the number of free nitrogen fixing, cellulose decomposing, phosphates decomposing and polysaccharide producing microorganism is $3.56 \times 10^{2}, 6.43 \times 10^{3}, 5.72 \times 10^{2}$, and $4.98 \times 10^{3} \mathrm{CFU} / \mathrm{g}$ respectively. The number of free nitrogen fixing and polysaccharide producing microorganism increases slightly through rehabilitation stages and reaches values of $5.24 \times 10^{3}$ and $5.39 \times 10^{4} \mathrm{CFU} / \mathrm{g}$ respectively at the rehabilitation stage of $\geq 20$ years; whereas the number of cellulose decomposing and phosphates decomposing microorganism increased 100-fold and reached values of $3.14 \times 10^{5}$ and $4.27 \times 10^{4} \mathrm{CFU} / \mathrm{g}$ respectively.

\section{CONCLUSION}

The study has made assessement on changes of some soil microorganism groups during the process of forest rehabilitation in Song $\mathrm{Ma}$ district, Son La province. In the forest group developed after shifting cultivation the total aerobic bacteria, the total actinomycetes and the total microfungi have increased from $3.12 \times 10^{2}$; $1.23 \times 10^{3}$ and $8.05 \times 10^{2} \mathrm{CFU} / \mathrm{g}$ respectively (at the rehabilitation stage of 4-6 years) to $3.54 \times 10^{5} ; 2.23 \times 10^{4}$ and $2.51 \times 10^{4} \mathrm{CFU} / \mathrm{g}$ respectively (at the rehabilitation stage of $\geq 20$ years). In the forest group developed after clear cutting the total aerobic bacteria, the total actinomycetes and the total microfungi have increased from $4.25 \times 10^{4} ; 2.32 \times 10^{3}$ and $7.32 \times 10^{3} \mathrm{CFU} / \mathrm{g}$ respectively (at the rehabilitation stage of $4-6$ years) to $4.35 \times 10^{6}$; $2.72 \times 10^{5}$ and $5.46 \times 10^{5} \mathrm{CFU} / \mathrm{g}$ respectively (at the rehabilitation stage of $\geq 20$ years).

The capacity in free nitrogen fixation, in cellulose decomposition, in phosphates decomposition, and in polysaccharide production of the aerobic bacteria, of actinomycetes, and of microfungi is lowest during the first forest rehabilitation stage, then it grows and reaches the highest value during the stage of $\geq 20$ years. The quantity of these microorganism groups in the forest group developed after clear cutting is 10 -fold higher than in the forest group developed after shifting cultivation. In the forest group developed after shifting cultivation, at the rehabilitation stage of $\geq 20$ years the number of free nitrogen fixing, cellulose decomposing and polysaccharide producing microorganism has been increased 100-fold, whereas the number of phosphates decomposing microorganism has been increased. In the forest group developed after clear cutting, through rehabilitation stages, the number of free nitrogen fixing and polysaccharide producing microorganism increases slightly, whereas the number of cellulose decomposing and phosphates decomposing microorganism increased 100fold.

Acknowledgment: This paper is the result of the IEBR (Institute of Ecology and Biological Resources, Vietnam) - NIBR (National Institute of Biological Resources, Korea) joint research project (2013-2014). We are thankful to the NIBR for the financial support.

\section{REFERENCES}

1. Nguyen Lan Dung, Pham Thi Tran Chau, Nguyen Thanh Hien, Le Dinh Luong, Doan Xuan Muou, 1978. Mot so phuong phap nghien cuu vi sinh vat hoc, vol. III. Science and Technics Publishing House, Hanoi.

2. John G. H., Noel R. K., Peter H. A. S., James T. S., Stanley T. W., 1986. Bergey's manual of Systematic Bacteriology, 9th Edition, 2.

3. Sunil T. P., Amarsinh A. B., Trishala B. G., Tejswini R. N., 2013. Isolation, screening 
and optimization of exopolysaccharide producing bacterium from saline soil. J. Microbiol. Biotech. Res., 3(3): 24-31.

4. TCVN 6166, 2002. Microbial nitrogen fixing fertilizer.

5. TCVN 6167, 1996. Phosphat-solubilizing microbial fertilizer.

6. TCVN 6168, 2002. Microbial preparation for cellulose degradation.

7. Nguyen Thi Thu, Nguyen Van Thao, Do
Thi Gam, Tran Đinh Man, Nguyen The Trang, Pham Thanh Ha, Tran Thi Hoa, 2013. Evaluation of microorganisms content in the planting soil of tea, coffee, black pepper in Tay Nguyen and selection of useful microbial combinations to investigate multifuntional biofertilizer for sustainable development crops. Proceedings. National Biotechnology Conference, 2: 568-572. Publishing House for Science and Technology.

\title{
NGHIÊN CÚU MỘT SỐ NHÓM VI SINH VÂT TRONG QUÁ TRÌNH PHỤC HỒI RÙ̉NG TẠI HUYỆ SÔNG MÃ, TỈNH SƠN LA
}

\author{
Nguyễn Thị Quyên ${ }^{1}$, Nguyễn Văn Sinh ${ }^{2}$ \\ ${ }^{1}$ Ủy ban Mặt trận tổ quốc huyện Sông Mã \\ ${ }^{2}$ Viện Sinh thái và Tài nguyên sinh vật, Viện Hàn lâm KH\&CN Việt Nam
}

\section{TÓM TÁT}

Bài báo đánh giá những thay đổi của một số nhóm vi sinh vật đất trong quá trình phục hồi rừng sau nương rẫy và sau khai thác kiệt tại huyện Sông Mã, tỉnh Sơn La. Việc thu mẫu được thực hiện trong các diện tích rừng tái sinh tự nhiên $4-6 ; 9-11 ; 14-16$ và trên 20 năm sau nương rẫy và sau khai thác kiệt. Kết quả đã cho thấy, tổng số vi khuẩn hiếu khí, tổng số xạ khuẩn và tổng số vi nấm tăng lên từ giai đoạn phục hồi 4-6 năm (tương ứng $3,12 \times 10^{2} ; 1,23 \times 10^{3}$ and $8,05 \times 10^{2} \mathrm{CFU} / \mathrm{g}$ trong các diện tích rừng sau nương rầy và tương ứng $4,25 \times 10^{4} ; 2,32 \times 10^{3}$ và $7,32 \times 10^{3} \mathrm{CFU} / g$ trong các diện tích rừng sau khai thác kiệt) đến giai đoạn phục hồi trên $\geq 20$ năm (tương ứng $3,54 \times 10^{5} ; 2,23 \times 10^{4}$ và $2,51 \times 10^{4} \mathrm{CFU} / \mathrm{g}$ trong các diện tích rừng sau nương rẫy và tương ứng $4,35 \times 10^{6} ; 2,72 \times 10^{5}$ và $5,46 \times 10^{5} \mathrm{CFU} / \mathrm{g}$ trong các diện tích rừng sau khai thác kiệt). Năng lực cố định nitơ tự do, phân giải xenlulose, phân giải photphat và sinh polysaccharit của vi khuẩn hiếu khí, xạ khuẩn và vi nấm thấp nhất trong giai đoạn phục hồi đầu (4-6 năm), sau đó tăng lên và đạt giá trị cao nhất ở giai đoạn $\geq 20$ năm (tương ứng $5,60 \times 10^{3} ; 2,75 \times 10^{4} ; 2,10 \times 10^{3} ; 1,36 \times 10^{4} \mathrm{CFU} / \mathrm{g}$ trong các diện tích rừng sau nương rẫy và tương ứng $5,24 \times 10^{3} ; 3,14 \times 10^{5} ; 4,27 \times 10^{4} ; 5,39 \times 10^{4} \mathrm{CFU} / \mathrm{g}$ trong các diện tích rừng sau khai thác kiệt).

Tư khóa: Phục hồi rừng, vi sinh vật đất, Sơn La, Việt Nam.

Ngày nhận bài: 15-6-2014 